\title{
Financial Feasibility Analysis of Mojosari Laying Duck Breeding Farm with Intensive Rearing System (Case Study at UD Sinar Harapan at Kedawung Village Blitar Regency East Java)
}

\author{
Isadora Turnip, Budi Rahayu Tanama Putri, I Wayan Sukanata \\ Faculty of Animal Husbandry, Udayana University, Denpasar-Bali, Indonesia
}

\begin{abstract}
This research aims to determine the management of maintenance, marketing, and analyze the financial feasibility of duck breeding farms with intensive rearing system. This research was conducted from May to June 2017 at UD. Sinar Harapan located at Kedawung Village, Blitar Regency, East Java. The data used were primary and secondary data. The financial feasibility level of this business was determined based on the analysis of investment criteria, Pay Back Period analysis, Break Even Point, and sensitivity analysis. Business duck breeding Mojosari of UD. Sinar Harapan was very concerned for several aspects, i.e. the selection of going, ranching, feeding, prevention and treatment of diseases, labor, and marketing. The results of this research showed that this business produced NPV for Rp 9,484,255,062 IRR for 167.07\%, Net B/C for 5.53, Pay Back Period for 0.95 year, and Break Even Point happened in 1,49 year. The sensitivity analysis result shows that this effort is sensitive to the change of egg selling price with sensitivity value $37.98 \%$ and less sensitive to the increase of feed price with sensitivity value $92.24 \%$. Based on the analysis of investment criteria that have been done can be concluded that duck breeding business Mojosari UD. Sinar Harapan is financially feasible.
\end{abstract}

Keywords: laying duck farming, Mojosari duck, intensive rearing system, financial feasibility

Author Correspondence:

Isadora Turnip,

${ }^{1}$ Faculty of Animal Husbandry, Udayana University, Denpasar

E-mail: isadoraturnip55@gmail.com.

\section{Introduction}

Livestock is breeding and cultivation activity of animal farm to obtain result and benefit of these activities. The purpose of farming is to seek profit by applying management principles to combined production factor optimally. Livestock in Indonesia consists of various types. One of them is poultry.

The poultry farming business in Indonesia currently experiences more advancing development compared to another livestock business relatively, it can be seen from its considerable contribution in expanding employment, increasing income of community and the main one is fulfilling the high nutritional food needs [1]. One of the poultry business is quite developed in Indonesia as duck business.

Ducks have considerable potential as producers of eggs and meat though not as popular as poultry. Ducks have an advantage of having a resistance to disease better than other birds. Therefore ducks have a smaller risk of failure due to disease [2].

Annual per capita consumption of duck eggs in Indonesia in 2011 to 2014 decreased by $46 \%$ from 2,816 grains to 1,512 grains, but with the increasing rate of economic growth in Indonesia it also has an effect on increasing per capita duck egg consumption per year in the year 2015 amounting to $41 \%$ from 1,512 grains to 2,138 grains per capita per year [1]. 
There are various types of ducks known in Indonesia as Mojosari duck, khaki Campbell duck, duck Tegal (Anas javanica), duck Bali (Anas sp), Magelang duck, and Javanese ducks. Mojosari duck is a superior local duck from the village of Modopuro, Mojosari District, Mojokerto Regency, East Java. According to [3], the Mojosari duck is smaller than other types of superior laying ducks, the Mojosari duck has relatively large eggs with the weight of about 65-70 g/granules. A maintained intensive Mojosari ducks with the cage system, egg production can reach an average of 265 grains/head/year.

The duck breeding business in Indonesia consists of several maintenance systems such as traditional maintenance system, semi-intensive maintenance system, and intensive (modern) maintenance system. The production of eggs which produced from the maintained ducks intensively gives more amount of eggs than semi-intensive duck eggs [4]. Currently, laying duck breeding pattern is still facing several problems such as maintenance pattern tend still be done traditionally, the business scale has not been economical yet and marketing access has not been optimal yet [2], [5].

According to [6], that in measuring the progress and success of a business can be reviewed from financial analysis, it is necessary to report financial analysis. According to [7], that in obtaining information about the feasibility of investment over the life of the investment, it is necessary having the analysis of investment criteria. The goal is to find out how far is this effort can provide benefit viewed from financial benefit [8].

\section{Material and Methods}

Data collection was done by survey method, interview using questionnaire, in-depth interview and observation to research location.

Analysis of investment criteria in this study is used to determine the feasibility of business delicate in terms of financial. The analysis used is Net Present Value (NPV), Internal Rate of Return (IRR), Net Benefit Cost Ratio (Net B/C). The formula used in the analysis [9] of investment criteria are:

1) Net Present Value (NPV)

Information:

Information:

NPV = Net Present Value

$B_{t} \quad=$ Benefit in year $\mathrm{t}(\mathrm{Rp})$

$C_{t} \quad=$ Costs incurred in year $\mathrm{t}(\mathrm{Rp})$

$\mathrm{i} \quad=$ Discount Rate $(\%)$

$\mathrm{t} \quad=$ Year period $(0,1,2, \ldots ., 10)$

2) Internal Rate of Return (IRR)

$$
\mathrm{IRR}=i_{1}+\frac{N P V_{1}}{N P V_{2}-N P V_{1}} x\left(i_{2}-i_{1}\right)
$$


Information:

$i_{1}=$ Discount rate rate that yields positive NPV

$i_{2}=$ Discount rate rate that yields negative NPV

$N P V_{1}=$ Net Present Value positive

$\mathrm{NPV}_{2}=$ Net Present Value Negative

3) Analisis Net Benefit Cost Ratio (Net B/C Ratio)

$$
\text { Net } \frac{B}{C}=\frac{\sum_{t=0}^{10} \frac{B_{t}-C_{t}}{(1+i)^{t}} \operatorname{Untuk}\left(B_{t}-C_{t}\right)>0}{\sum_{t=0}^{10} \frac{C_{t}-B_{t}}{(1+i)^{t}} \operatorname{Untuk}\left(B_{t}-C_{t}\right)<0}
$$

Information:

$B_{t}=$ Benefit in year $\mathrm{t}$.

$C_{t}=$ Costs incurred in year $\mathrm{t}$.

$\mathrm{i}=$ Discount Rate $(\%)$

$\mathrm{t}=$ Year period $(0,1,2, \ldots, 10)$

Payback Period (PBP) and Break Even Point (BEP) analyzes [9] are used to determine business feasibility at UD. Ray of hope. The formula used in this calculation is:

1) Pay Back Period (PBP)

$$
P B P=T_{p-1}+\frac{\sum_{t=0}^{10} \bar{I}_{t}-\sum_{t=0}^{10} \bar{B}_{t c p-1}}{B_{p}}
$$

Information:

PBP = Pay Back Period.

$T_{p-1}=$ Year before PBP.

$\bar{I}_{t} \quad=$ Cumulative investments that have been discounted

$\bar{B}_{t c p-1}=$ Cumulative Benefit has been discounted until the year before PBP

$\bar{B}_{p} \quad=$ Number of benefits to PBP.

$\mathrm{t} \quad=$ Year period $(0,1,2, \ldots, 10)$

2) Break Even Point (BEP)

$$
B E P(\text { tahun })=T_{p-1}+\frac{\sum_{t=0}^{10} \overline{T C}_{t}-\sum_{t=0}^{10} \bar{B}_{t c p 1}}{B_{p}}
$$


Information:

$T_{p-1} \quad=$ Year before BEP

$\overline{T C}_{t}=$ Cumulative total Cost that has been discounted.

$\bar{B}_{t c p-1}=$ Cumulative benefits that have been discounted until the year.

before the BEP is located.

$B_{p} \quad=$ Number of benefits on BEP is.

$\mathrm{t} \quad=$ Year period $(0,1,2, \ldots ., 10)$.

Analysis of the sensitivity (Switching Value) company, in particular, the effect of changes in feed prices and egg prices are calculated using the formula [9]:

a) Switching Value Increase in Feed Prices

$$
S V . H P=H P_{1}+\frac{N P V_{1}}{N P V_{1}-N P V_{2}}\left(H P_{2}-H P_{1}\right)
$$

Information:

V.HP = Switching value of feed price.

NPV1 = Net Present Value indicating a positive number

NPV2 = Net Present Value showing the negative number

HP1 = Feed price that yields NPV1

HP2 = Feed prices that generate NPV2

b) Switching Value Egg Prices Decrease

$$
S V . H T=H T_{1}+\frac{N P V_{1}}{N P V_{1}-N P V_{2}}\left(H T_{2}-H T_{1}\right)
$$

Information:

SV.HT $=$ Switching value of egg price

NPV1 = Net Present Value indicating a positive number

NPV2 = Net Present Value showing the negative number

HT1 = Price of eggs that produce NPV1

HT2 = Price of eggs that produce NPV2

\section{Results and Discussion}

\subsection{A general description of the company}

Laying duck farm Mojosari UD. Sinar Harapan has been established since 1990. This farm is located in Kedawung Village, Nglego District, Blitar Regency, East Java. The types of ducks which are kept on farms. UD. Sinar Harapan is a layer duck Mojosari type with intensive maintenance system. The number of livestock kept currently is 10,000 ducks managed by Mr. Ashadi and 3 employees. The purpose of this farm is to produce eggs and sell ducks reject. The average number of eggs produced on this farm is $2,451,550$ eggs/year and the average number of reject ducks is $9,947 /$ period. 
Financial Feasibility Analysis of Mojosari Laying Duck Breeding Farm with Intensive Rearing System (Case Study at UD Sinar Harapan at Kedawung Village Blitar Regency East Java)

\subsection{The management of maintenance}

Laying ducks are kept in UD. Sinar Harapan is a type of Mojosari obtained by buying a 4 months old duck or ready to spawn duck from one of the farmer groups in Kedawung village with an average price of Rp 65,000. Type selection of Mojosari maintained ducks at UD. Sinar Harapan based on several points: 1) availability of ducks Type Mojosari in the location of the business quite a lot, 2) Mojosari duck has the advantage that can results average eggs as much as 265 grains/tail/year, 3) long productive period of 24 months.

Types of cages used on laying duck farms UD. Sinar Harapan is battery enclosure type. The battery enclosure is a cage made with barriers and each partition contains only 1-2 cattle (Kaleka, 2015). The benefits of using a battery cage are livestock productivity more controlled, egg-producing easy to get.

In UD. Sinar Harapan, the given feed is a mixed feed itself because the feed material is widely available in the area of business location. In addition to the cheaper feed prices, the company also becomes independent of the feed mill. The firm is not affected by rising feed prices on the market. This is supported by the statement [10] which states that ransom should be compiled by using quality feed ingredients, cheap, and easy to find. Mixed feed ingredients used in UD. Sinar Harapan is a mixture of fine bran, bran/kebi, concentrate, Karak (dry rice), and grits. The amount of fine bran for laying ducks in UD. Sinar Harapan is $8 \%$ out of all feed ingredients, $60 \%$ bran/kebi, $27 \%$ concentrate, $4 \%$ grain, and $1 \%$ grit. Feeding with the natural mixture is more cost-effective than commercially. Price of manufacturer feed $\mathrm{Rp} 4,500$ to $\mathrm{Rp5}, 000$ while the natural mixture is $\mathrm{Rp} 4,098$.

At UD. Sinar Harapan cattle raised ducks were given an average of 160 grams of feed per day. This is in accordance with what reported by [11] the need for duck feed on layer phase or egg laying that is above 20 weeks need feed 160-180 g/day. Feeding on the farm is done twice a day that is, in the morning at $07.00 \mathrm{am}$ and in the afternoon at $16.00 \mathrm{pm}$.

The number of the worker at UD. Sinar Harapan is a three-person who is the owner's child, the administration is directly handled by owners. Workers work for 10 hours from 06.00 am until $16.00 \mathrm{pm}$. Workers (employees) get a salary of Rp. 1,800,000, -/month. The salary received has already exceeded

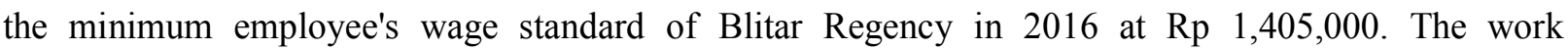
undertaken includes, collecting eggs at $06.00 \mathrm{pm}$, then continued to provide feed on livestock at 07.00 pm. Next count the number of eggs produced. Furthermore, at $16.00 \mathrm{pm}$ to do feedback on ducks.

Prevention of disease done by laying duck farming UD. Sinar Harapan is doing sanitation, vaccination, and biosecurity. Cage sanitation at UD. Sinar Harapan of hope are done by several stages before the animals enter the cage or the cage preparation stage, daily sanitation is by cleaning the feeding place from the remnants of feed before the feed is given back, and sanitation of the cage at the end of the livestock raising period or after the livestock in reject. Vaccination is done when new ducks come, by injecting avian influenza vaccine (AI). [12] describes AI is a disease caused by a virus and can cause respiratory disease up to death in various poultry and mammals with a dose of $0.5 \mathrm{ml} / \mathrm{head}$. Biosecurity carried out in this company is the location of the farm has been built $2 \mathrm{~m}$ high wall with one entrance, so the owner can limit the entry of people, animals, and equipment to the farm.

At the beginning of production in laying duck farming UD. Sinar Harapan, laying cattle can reach 50 $-60 \%$, while at peak production percentage of eggs can reach $80 \%$. Then the cattle will reject when aged 29-30. In this farm, the resulting eggs are grouped into two types namely large egg (AB) and small egg 
Financial Feasibility Analysis of Mojosari Laying Duck Breeding Farm with Intensive Rearing System (Case Study at UD Sinar Harapan at Kedawung Village Blitar Regency East Java)

(BK). In an average period of egg production (AB) as much as $99.5 \%$ and small eggs (BK) as much as $0.5 \%$. The average selling price of eggs (AB) is Rp1,873/egg and small egg (BK) Rp1,257/grain.

\subsection{Cash Flow}

Cash flow of laying duck farming business UD. Sinar Harapan with intensive maintenance system and maintenance scale of 10,000 tail consists of investment cost and operational cost. The cost of business investment is $\mathrm{Rp} 2,696,680,000$ which covers the cost of building the cage, feed warehouse, egg warehouse, office, cage equipment, office equipment, land rent, vehicle, electrical installation and drilling well and duck purchasing.

Operational costs are divided into two, namely fixed costs, including depreciation of buildings and equipment, land, electricity, telephone, and labor costs of Rp 420,562,250 and variable costs include purchases of feed and medical expenses of $\mathrm{Rp} 2,007,681,471$. The average operating expenses incurred each year is $\operatorname{Rp} 2,242,121,221$ with an average number of livestock 9.991 tails per year.

\subsection{Financial feasibility analysis}

The results of this study indicate that duck breeding business. UD. Sinar Harapan which uses intensive maintenance system financially feasible This can be seen from the results of feasibility analysis presented in Table 1.

Net present value (NPV) of laying duck farms on UD. Sinar Harapan is positive, amounting to Rp $9,484,255,062$ which means within a period of 8 years, the business of laying duck farms UD. Sinar Harapan was able to give a net profit amounting to $\operatorname{Rp} 9,484,255,062$ in the form of present value (present value).

Table 1

The result of Analysis of Laying Duck Farming at UD. Sinar Harapan

\begin{tabular}{|l|l|l|l|}
\hline No & Financial feasibility analysis & Result & Description \\
\hline 1 & NPV (Net Present Value) & Rp $9,484,255,062$ & NPV positive \\
\hline 2 & IRR (Internal Rate of Return) & $167.07 \%$ & IRR $>$ DF $16 \%$ \\
\hline 3 & Net B/C (Net Benefit Cost Ratio) & 5.53 & Net B/C $>1$ \\
\hline 4 & PBP (Pay Back Period) & 0.95 & Period of refunds investment cost \\
\hline 5 & BEP (Break Even Point) & 1.49 & time of return of all charges \\
\hline
\end{tabular}

IRR value must be greater than the interest rate that is of $16 \%$. The results of the calculations that have been done, then the value of the IRR obtained on this company is of $167.07 \%$ this means the business is able to provide benefits to the level of the discount rate of $167.07 \%$ and when the level of the discount rate was on top this effort then $167.07 \%$ unfit to run.

The results of calculations on the interest rate of $16 \%$ per annum has been done, then the obtained Net B/C of 5.53 this means every one rupiah issued for business activities will provide a net benefit of 5.53 meaning that this effort deserves to be in the run, it is in accordance with the statement of [9], which States that if the net results obtained $\mathrm{B} / \mathrm{C}>1$, then the business is eligible to run. Based on the calculations that have been done, payback period (PBP) business of laying duck farms UD. Sinar Harapan is 0.95 years. This means that the business is able to restore the investment costs in a period of 11 months or years of 0.95 . This suggests that this effort deserves to be executed because it is capable of restoring the entire cost of investment before the end of the project period ( 8 years). Break Event Point 
Financial Feasibility Analysis of Mojosari Laying Duck Breeding Farm with Intensive Rearing System (Case Study at UD Sinar Harapan at Kedawung Village Blitar Regency East Java)

of laying duck farm UD. Sinar Harapan is 149 years. This suggests that this effort breaks even at a time when such business running for 1.49 years.

\subsection{Sensitivity}

To know the sensitivity level of laying duck farms do with the analysis of the switching value. Feasibility sensitivity to know the effort that's been obtained against the changes increased the price of feed and a decrease in the price of eggs. Based on the results of the sensitivity analysis performed calculations obtained results as Table 2 .

Table 2

The Results of The Sensitivity Analysis

\begin{tabular}{|l|l|l|l|}
\hline Parameters & Switching Value (Rp) & Sensitivity & Description \\
\hline The increase in the price of feed & $\operatorname{Rp~} 7,878,018$ & $92.24 \%$ & Less sensitive \\
\hline The drop in the price of eggs & $\operatorname{Rp~} 1,159,900$ & $37.98 \%$ & Sensitive \\
\hline
\end{tabular}

Based on the sensitivity analysis has been done found that feed price sensitivity of $92.24 \%$ (less sensitive) and the sensitivity of the price of eggs $37.98 \%$ (sensitive) which means that the company will suffer losses if an increase in feed prices up to more than $92.24 \%$, or if there is a drop in the price of eggs is greater than $37.98 \%$.

\section{Conclusion}

Management of laying duck as duck election management Dara, cage, feed, prevention and treatment of diseases, manpower, and marketing has been done UD. Sinar Harapan nicely. The business of laying duck farms UD. Sinar Harapan to be financially viable to run, which is indicated by a value of Rp 9,484,255,062 NPV IRR $167.07 \%$ and Net B/C of 5.53. The business is able to restore the investment cost has been incurred in a period of 11 months, and break even after these attempts 1.52 runs for years. The results of the sensitivity analysis showed that the business of laying duck farms UD. Sinar Harapan with an intensive maintenance would suffer losses in the event of an increase in the price of feed is more of $92.24 \%$ and a decrease in the price of eggs over $337.98 \%$ of the normal price.

\section{Acknowledgments}

The author says many thanks to Mr. Dr. Ir. Ida Bagus Gaga Partama, MS as the Dean of Faculty animal husbandry Udayana University, Mr. Ashadi as the owner of laying duck farms, as well Faculty Udayana University Lecturer that has a lot to give advice and enter in this thesis.

\section{References}

[1] Ditjen PKH, (2016). Statistik Peternakan dan Kesehatan Hewan. 2016. Direktorat Jenderal Peternakan dan Kesehatan Hewan. Kementerian Pertanian.

[2] Budiraharjo, K. (2009). Analisis Profitabilitas Pengembangan Usaha Ternak Itik Di Kecamatan Pagerbarang Kabupaten Tegal. J. Mediagro.

[3] Kaleka, N. (2015). Beternak Itik Tanpa Bau Tanpa Angon. ARCITRA, Yogyakarta.

[4] Retno \& Sitanggang, M. (2007). Panduan Lengkap Beternak Itik. Agromedia Pustaka, Jakarta.

[5] Handayani, M., Setiadi, A., Gayatri, S., \& Setiyawan, H. (2007). Profil Usaha Peternakan Itik Di Kabupaten Brebes (The Profile of Duck Business in Brebes Regency). Journal of Animal Agricultural Socio -economics. Laboratorium Sosial Ekonomi Peternakan. Fakultas Peternakan. Universitas Diponegoro.

[6] Bambang, R. (1991). Dasar-dasar Pembelanjaan Perusahaan. Yayasan Penerbit Gajah Mada. Yogyakarta.

[7] Kasmir \& Jakfar (2003). Studi Kelayakan Bisnis. Prenada Madia, Jakarta. 
Financial Feasibility Analysis of Mojosari Laying Duck Breeding Farm with Intensive Rearing System (Case Study at UD Sinar Harapan at Kedawung Village Blitar Regency East Java)

[8] Yacob, I.H.M. (2003). Study Kelayakan Bisnis (Edisi Revisi). PT. Rineka Cipta, Jakarta.

[9] Ibrahim, H.M.Y. (2003). Studi Kelayakan Bisnis. Rineka Cipta, Jakarta

[10] Setioko, A.R. (1992). Kebutuhan Pakan Itik. Palembang.

[11] Prasetyo, L.H, Kateran P.P, Setioko, A.R., Suparyanto, A., Juwarini E., Susanti, T., \& Sopiyana, S. (2010). Panduan Budidaya dan Usaha Ternak Itik. Balai Penelitian Ternak, Bogor.

[12] Sudarisman (2006). Pengaruh Penggunaan Vaksin H5N1 dan H5N2 Virus Avian Influenza pada Peternakan Unggas di Daerah Jawab Barat. Balai Penelitian Veteriner. Bogor. 